\title{
Preface to the Twenty-fifth Anniversary Edition
}

The year 2009 is an appropriate one in which to bring out an updated version of this book. Celebrations are being held all around the world to mark the bicentenary of Darwin's birth and the 15oth anniversary of the publication of his On the Origin of Species. In anticipation of these events, many publications are already in press (some of which are mentioned later in this preface) and more will no doubt emerge from the conferences that are planned. These will add to the steady stream of literature on the history of evolutionism that has appeared in the five years since the previous edition of this book. This revised version is issued with the aim of alerting readers to some of the more significant recent publications and assessing their implications. It has proved impractical to incorporate this material into a revised version of the main text, so this preface will provide the necessary information and comment, including a supplementary bibliography.

Perhaps the most obvious point to make is that most people now get their information on this (and any other) topic from the Internet. But on a highly controversial topic such as evolutionism, the Internet can be an unreliable source. Typing evolution into a search engine will bring up literally millions of sources, and most of those at the head of the list will be commercial sites that have just borrowed the term in their names. More seriously, typing in Darwinism will bring up far more sites concerned with the social implications of the theory than with the science. No search will proceed very far without coming across Web sites maintained by creationist organizations (see www.talkorigins.org for a more balanced approach). Web sites relating to creationism or biology and human nature are obviously intended as contributions to ongoing debates, but they often include material on the historical background to modern positions. Scholars recognize 
that interpretations of historical events offered by highly partisan organizations may reflect those organizations' wider agendas, but this may not be obvious to the casual observer.

Fortunately, there are reputable and extremely useful Web sites to consult for information on some of the more important figures in the development of evolutionary thought. The most important is the enormous compilation of Darwin's own work and associated material offered at www .darwin-online.org.uk. Darwin's notebooks and some other sources are available at www.darwinlibrary.amnh.org and the correspondence at www .darwinproject.ac.uk. There are also sites devoted to Lamarck (www.lamarck .cnrs.fr) and A. R. Wallace (www.wku.edu/ smithch/). To find examples of the popular debates, try searching the Science in the Nineteenth-Century Periodical site at www.sciper.org.

Turning to the printed literature, there have been some notable studies of the history of the earth sciences, including two massive volumes by Martin Rudwick: Bursting the Limits of Time, on the developments leading up to and including the work of Georges Cuvier, and Worlds before Adam, on the period centered on subsequent developments in the early nineteenth century. Rudwick argues that the modern view of the earth's past emerged as an extension of the historical method, based on a growing recognition that the only way of reconstructing the sequence of events was from the surviving evidence in rocks. Models based on physical principles (such as the cooling earth theory) were incapable of explaining the complexity of the record. Ralph O'Connor's The Earth on Show explores popular representations of the earth's past in the early nineteenth century. Jack Morrell's John Phillips and the Business of Victorian Science throws new light on this major figure in midcentury geology.

In the pre-Darwinian period, the wider context within which evolutionism was developed has been explored by a number of scholars. Jon Hodge's seminal articles on figures such as Lamarck and Chambers have been reprinted in a collected volume, Before and after Darwin. John Van Wyhe's Phrenology and the Origins of Victorian Scientific Naturalism offers new insights on the wave of enthusiasm for this radical new vision of human nature. J. F. M. Clark's article on William Kirby and William Spence's Introduction to Entomology reveals the complex ideological differences between these very different supporters of natural theology. Laura Snyder's Reforming Philosophy studies the debates between William Whewell and John Stuart Mill and helps us to understand some of the issues underlying early nineteenth-century attitudes to evolutionism in Britain. Richard Bellon's "Joseph Hooker Takes a 'Fixed Post'" and Jim Endersby's Imperial Nature 
both show how the confused state of plant classification at the time shaped Hooker's early attitude toward evolutionism.

There have been major developments in the study of nineteenth-century German science. Nicolaas Rupke's "metabiography" of Alexander von Humboldt breaks new ground on this major influence on Darwin by revealing the different ways in which his work has been depicted by successive generations of commentators. Sander Gliboff's H. G. Bronn, Ernst Haeckel, and the Origins of German Darwinism reassessed the German morphological tradition, reinforcing the argument that it moved far beyond the transcendentalism with which it used to be associated. In particular, Gliboff shows that the morphologists were keenly interested in the diversity as well as the unity of life, and that the so-called Meckel-Serres law of the parallelism between the development of the embryo and the history of life on earth was never intended to be understood in the simpleminded way portrayed by historians such as E.S. Russell and Stephen Jay Gould. The more sophisticated view of the development of life on earth was consolidated in the work of the paleontologist H.G. Bronn, who subsequently translated Darwin's Origin of Species (on which more later).

Richard Owen's On the Nature of Limbs brought German ideas on morphology into Britain, and has now been reprinted, edited by the philosopher of science Ron Amundson. Amundson also has a more general work, The Changing Role of the Embryo in Evolutionary Thought, arguing for a reassessment of the developmental approach to biology in the light of modern evolutionary developmental biology (evo-devo). His analysis is marred by a somewhat black-and-white categorization of the material but the point he makes is important: if modern biologists no longer see neo-Darwinism as the goal toward which evolutionary science has been moving, then we do need to rethink our attitudes toward the non-Darwinian approaches that focus on form (the underlying structure of organisms) rather than function (adaptive modifications). The expectation that "laws of development" were crucial for understanding the course of evolution shaped most pre-Darwinian versions of evolutionism and would reemerge as an important component of the non-Darwinian evolution theories that became popular in the later nineteenth century (see the discussion later in this preface).

Amundson's thesis thus moves in the opposite direction to Gliboff's, since the latter brings out the extent to which the morphologists sought to accommodate the diversity of life into their system. These conflicting interpretations reinforce the need for a much more sophisticated model of the conceptual issues at stake in the pre- and post-Darwinian eras. Concern 
for the laws of development was characteristic of those morphologists who focused on the deep structure of organisms, but it occasionally emerged in the study of the later stages of ontogeny and phylogeny, where it encouraged the formulation of non-Darwinian models that minimized the role of adaptation. But as Gliboff shows, there were other morphologists who tried to understand the production of diversity against a background of underlying order, and these were more receptive to the Darwinian view in which evolution was less rigidly directed by built-in forces.

Moving to Darwin himself, volumes of his correspondence continue to appear at regular intervals, and there are several new collections (listed later) aimed at a more general audience. There are collected volumes in which major scholars in the field offer comprehensive overviews of their positions, including The Cambridge Companion to Darwin (edited by Jon Hodge and Greg Radick) and The Cambridge Companion to the Origin of Species (edited by Michael Ruse and Robert Richards). Ruse has also edited a collection of papers on the "Darwinian Revolution" in the Journal of the History of Biology. Jon Hodge's Darwin Studies brings together his important studies of Darwin's thinking.

Important work continues to be done on early Darwin. Sandra Herbert's Charles Darwin, Geologist gives us the first really comprehensive account of his work in this field. She argues that his work constituted an attempt to formulate a comprehensive theory in which movements of the earth's crust played the central role. Adrian Desmond and James Moore's Darwin's Sacred Cause offers a controversial interpretation in which Darwin's hatred of slavery played a major role in driving him toward evolutionism, a position trailed in their introduction to a recent edition of his Descent of Man. They argue that his determination to show that all human races have descended from a common ancestor prompted him to explore a more general model of common descent. John Van Wyhe's "Mind the Gap" has controversially argued against the view that Darwin delayed publication of his theory for fear of its religious implications.

Studies of Darwin's early interests bear on what seems to have emerged as the most divisive fault line in the modern Darwin industry, the question of his indebtedness to Romanticism. Michael Ruse's "The Romantic Conception of Robert J. Richards" challenges the efforts Richards has made in previous studies to enroll Darwin as an honorary Germanic thinker, a position also supported in Phillip Sloan's "The Sense of Sublimity.'" Richards has responded in his "Michael Ruse's Design for Living" and in his new biography of Ernst Haeckel (discussed later). Richards cites Darwin's progressionism and his commitment to the recapitulation theory as evidence 
of Germanic influence, while Ruse insists that these elements are less central to Darwin's thought than natural theology, utilitarianism, and Lyell's geology are. To complicate matters, Gliboff's book supports the link between Darwin and Haeckel, but insists that Richards is exaggerating the role of recapitulationism throughout this period. The key question is whether a Romantic influence was necessary to turn Darwin toward a more historical vision of nature. The study by Adrian Desmond and James Moore cited earlier is relevant here because it suggests another factor pushing Darwin toward the idea of descent. On this topic Stephen Alter offers an important new insight that helps us to understand how Darwin could have turned utilitarianism into a historical approach to nature. His "Mandeville's Ship" refers to the social commentator Bernard Mandeville, an exponent of freeenterprise liberalism, who used the metaphor of a ship, designed not by a single super-intelligent shipwright but by generations of artisans tinkering to produce minor improvements.

Alter is also one of the few historians still adding to our understanding of the detailed functioning of Darwin's theory with his "Darwin and the Linguists." James Moore's "Revolution of the Space Invaders" compares Darwin's and Wallace's views on biogeography. Another valuable comparison is Melinda Fagan's "Wallace, Darwin and the Practice of Natural History," while Martin Fichman's An Elusive Victorian shows us how Wallace was able to pull the apparently contradictory aspects of his thought together.

The response to Darwinism continues to attract much attention. Paul White's study of T. H. Huxley shows how hard Huxley worked to construct his image as a "man of science." I have provided a short overview of the religious debates intended to introduce students to the complexity of the reactions in my Monkey Trials and Gorilla Sermons. Gowan Dawson's Darwin, Literature and Victorian Sensibility gives us a sophisticated study of the literary response to Darwinism, highlighting the ease with which the theory could be portrayed as morally ambiguous. A more general collection on the response to Darwin is Darwinian Heresies, edited by Abigail Lustig, Robert Richards, and Michael Ruse. On the topic of human origins, Greg Radick's The Simian Tongue breaks new ground on the study of the origin of language. Marianne Sommer's Bones and Ochre illustrates the complex transitions that can take place in the interpretation of a single hominid fossil. The topic of human evolution also figures strongly in Brian Regal's study of the evolutionism of Henry Fairfield Osborn. David Livingstone's Adam's Ancestors explores the religious and ideological dimensions of the polygenist view of human origins.

Ernst Haeckel continues to attract much attention, and here again we 
encounter the question of the extent to which the German popularizer of the theory transformed Darwinism into something significantly different from what was presented in the Origin of Species. There are two major studies, both highlighting the wider dimensions of Haeckel's thought, Mario Di Gregorio's From Here to Eternity and Robert Richards's The Tragic Sense of Life. The latter contributes to Richards's established program seeking to identify Darwin with the Germanic tradition, but hostile readers will focus more on the evident differences between Darwin's and Haeckel's approaches. Topics such as artificial selection and island biography are scarcely mentioned, while Richards circles back on several occasions to the question of whether Haeckel faked the illustrations used to support his vision of evolution unfolding like the developing embryo. The latter topic is also discussed in Nick Hopwood's "Pictures of Evolution and Charges of Fraud." Amundson's survey of developmentalism, already noted, is also important in this area, as is the more balanced analysis From Embryology to Evo-Devo, edited by Manfred Laublichler and Jane Maienschein.

Gliboff's book, noted earlier, situates Haeckel in a wider context and, like Di Gregorio's study, takes a more balanced position on the question of whether Haeckel's vision of evolutionary progress differed significantly from Darwin's. Analysis of H.G. Bronn's position is important because Bronn provided the German translation of the Origin of Species on which Haeckel relied. Gliboff shows that Bronn's view of the history of life on earth was much more sophisticated than most commentators have assumed, preparing him to appreciate some of Darwin's arguments. Yet Bronn found it very hard to come to grips with some parts of Darwin's project, most obviously his work on animal breeding and artificial selection-topics that also played only a small role in Haeckel's Darwinism. To defend the link between Haeckel and Darwin, Gliboff argues that the latter did not emphasize the Lamarckian idea of variation by terminal addition, making his version of the recapitulation theory very different from that propounded by the American neo-Lamarckians. Haeckel focused mainly on the very early stages in the development of life, arguing that remnants of the deepest stages of ontogeny could be retained and thus provide at least some traces of phylogenetic history in later organisms. This is very different from the recapitulationism of E. D. Cope and Alpheus Hyatt, who followed Louis Agassiz in seeing adult forms from the past being recapitulated in the later stages of development.

Much of the heat in the debate between Richards and his opponents (myself included) may have been generated by a failure to appreciate the extent of this difference. Haeckel's recapitulationism is closer to the 
position held by Darwin - but neither was endorsing what the American paleontologists would have regarded as the key tenet of the theory (the retention of adult stages of recent ancestors). The extent of the difference has been concealed by the tendency of most Haeckel experts to focus on the distance between his thinking and that of earlier German biologists. Those--including Stephen Jay Gould-who saw Haeckel as a died-in-thewool developmentalist have tended to identify his recapitulationism with the American neo-Lamarckians' position. It may turn out that here we have significantly different ideas promoted under the same name, an obvious source of confusion.

Recognizing this point, however, still leaves us with the question of why Haeckel endorsed many aspects of the developmentalist viewpoint by insisting on a law of progress and sidelining the vast amount of adaptive change that is nonprogressive or even degenerative. Gliboff and Richards insist that he did take natural selection seriously and was fully aware of the unpredictable effects of divergent, adaptive evolution; they see these as essential components of his hostility to teleology. But other scholars sense a lack of real interest in those aspects of Darwin's theory that suggest the open-endedness of evolution and a preference for some form of built-in direction. This preference may have manifested itself more as support for a generalized progressive urge (akin to Henri Bergson's later idea of the élan vital) than for rigidly predetermined trends, which would certainly make Haeckel closer to Darwin than to American neo-Lamarckians. But it still implies a significant element of developmental thinking, possibly reflecting the emotional and ideological factors that Di Gregorio and Richards highlight.

Developments in the late nineteenth and early twentieth centuries continue to receive attention. Helen Blackman has studied British evolutionary morphology, while James G. Tabery shows that G. Udny Yule's early suggestion for a "synthesis" between Mendelism and biometry was nothing of the sort. Sander Gliboff has provided additional insights into the work of the Lamarckian experiments of Paul Kammerer. Michael Bulmer makes a useful addition to the list of biographies of Francis Galton, while James Moore's "R. A. Fisher: A Faith Fit for Eugenics" unpacks the complex relations between religious faith and ideology in the work of this founder of modern Darwinism.

This topic leads us into the much-debated area of the social implications of Darwinism. Mark Francis's Herbert Spencer and the Invention of Modern Life offers an important corrective to the still-popular image of Spencer as a social Darwinist wedded to an ideology of progress through struggle. 
Francis emphasizes that Spencer was not trying to develop an evolutionary theory parallel to Darwin's and shows that his later thought was much more pessimistic than the system attributed to him by his followers, including the so-called social Darwinists. Here, as with Haeckel, we are beginning to see just how complex the process was by which Darwinism was extended into a series of competing ideologies of progress. Richard Weikart's account of social Darwinism in Germany, From Darwin to Hitler, has attracted much critical attention, fueled in part by the author's links to the intelligent design movement. Weikart revives the old claim that Darwinism, as transmitted into Germany by Ernst Haeckel, played a role in creating the situation within which Nazism arose. Robert Richards's biography of Haeckel provides a rebuttal of this claim, pointing out that Darwinism was but one of many sources of nineteenth-century race theory. My own feeling, however, is that Weikart may have a stronger case with respect to an insight that played a relatively minor role in Haeckel's own thinking: Darwin's use of the analogy with artificial selection to identify the elimination of the unfit as a necessary factor in maintaining the biological quality of a race. Although it seems to have taken several decades for this idea to mature into the eugenics movement, the idea represents a significant input into the social debates, which it is hard to see coming from any other source.

Because of Weikart's own beliefs, the debate over his book feeds into the more general modern controversies over creationism and the intelligent design movement now becoming active throughout the world. Every effort is being made to discredit Darwinism both by questioning its scientific credentials and by claiming that it has harmful social and moral implications. The historical origins of modern creationism are traced in my own Monkey Trials and Gorilla Sermons and in Michael Ruse's The Evolution-Creation Struggle. Adam B. Shapiro has thrown new light on the origins of the antievolution movement in American schools, while a new edition of Ronald Numbers's classic book The Creationists adds chapters on the spread of the movement outside the United States. This is a debate that is not going to go away.

Queen's University, Belfast April 2009 


\section{REFERENCES FOR THE TWENTY-FIFTH ANNIVERSARY EDITION}

Alter, Stephen G. 2007-2008. "Darwin and the Linguists: The Coevolution of Mind and Language." Stud. Hist. and Phil. Biol. and Biomed. Sci. 38: 573-584 and $39: 38-50$.

_ 2008. "Mandeville's Ship: Theistic Design and Philosophical History in Charles Darwin's Vision of Natural Selection." J. Hist. Ideas 69: 441-465.

Amundson, Ron. 2005. The Changing Role of the Embryo in Evolutionary Thought: The Roots of Evo-Devo. Cambridge: Cambridge University Press.

Bellon, Richard. 2006. "Joseph Hooker Takes a 'Fixed Post': Transmutation and the 'Present Unsatisfactory State of Systematic Botany.' J. Hist. Biol. 39: 1-39.

Blackman, Helen J.2007. "The Natural Sciences and the Development of Animal Morphology in Late Victorian Cambridge." J. Hist. Biol. 40: 71-108.

Bowler, Peter J. 2007. Monkey. Trials and Gorilla Sermons: Evolution and Christianity from Darwin to Intelligent Design. Cambridge, Mass.: Harvard University Press.

Bulmer, Michael. 2003. Francis Galton: Pioneer of Heredity and Biometry. Baltimore: Johns Hopkins University Press.

Clark, J. F. M. 2006. "History from the Ground Up: Bugs, Political Economy and God in Kirby and Spence's Introduction to Entomology." Isis 97: 28-55.

Darwin, Charles Robert. 2004. The Descent of Man. Introduction by James R. Moore and Adrian Desmond. New York: Penguin.

- 2008a. Charles Darwin: The Beagle Letters. Ed. Frederick Burkhardt. Cambridge: Cambridge University Press.

- 2008b. Evolution: Selected Letters of Charles Darwin, 1860-1870. Ed. Frederick Burkhardt, Alison Pearn, and Samantha Evans. Cambridge: Cambridge University Press.

- 2008c. Origins: Selected Letters of Charles Darwin, 1822-1859. Ed. Frederick Burkhardt. Cambridge: Cambridge University Press.

Dawson, Gowan. 2007. Darwin, Literature and Victorian Respectability. Cambridge: Cambridge University Press.

Desmond, Adrian, and James R. Moore. 2009. Darwin's Sacred Cause: Race, Slavery and the Quest for Human Origins. London: Allen Lane.

Di Gregorio, Mario A. 2005. From Here to Eternity: Ernst Haeckel and Scientific Faith. Goettingen: Vandenhoek and Ruprecht.

Endersby, Jim. 2008. Imperial Nature: Joseph Hooker and the Practicalities of Victorian Science. Chicago: University of Chicago Press.

Fagan, Melinda B. 2007. "Wallace, Darwin and the Practice of Natural History." J. Hist. Biol. 40: 601-635.

Fichman, Martin. 2004. An Elusive Victorian: The Evolution of Alfred Russel Wallace. Chicago: University of Chicago Press.

Francis, Mark. 2007. Herbert Spencer and the Invention of Modern Life. Stocksfield, U.K.: Acumen.

Gliboff, Sander. 2006. "The Case of Paul Kammerer: Evolution and Experimentation in the Early Twentieth Century." J. Hist. Biol. 39: 525-563. 
2008. H. G. Bronn, Ernst Haeckel, and the Origins of German Darwinism: A Study in Translation and Transformation. Cambridge, Mass.: MIT Press.

Herbert, Sandra. 2005. Charles Darwin, Geologist. Ithaca, N.Y.: Cornell University Press.

Hodge, M. J. S. 2008a. Before and after Darwin: Origins, Species, Cosmogonies. Aldershot: Ashgate.

. 2008b. Darwin Studies: A Theorist and His Theories in Their Context. Aldershot: Ashgate.

Hodge, M. J. S., and Gregory Radick, eds. 2003. The Cambridge Companion to Darwin. Cambridge: Cambridge University Press.

Hopwood, Nick. 2006. "Pictures of Evolution and Charges of Fraud: Ernst Haeckel's Embryological Illustrations." Isis 97: 260-301.

Laublichler, Manfred D., and Jane Maienschein, eds. 2007. From Embryology to Evo-Devo: A History of Developmental Evolution. Cambridge, Mass.: MIT Press.

Livingstone, David N. 2008. Adam's Ancestors: Race, Religion, and the Politics of Human Origins. Cambridge, Mass.: Harvard University Press.

Lustig, Abigail, Robert J. Richards, and Michael Ruse, eds. 2004. Darwinian Heresies. Cambridge: Cambridge University Press.

Moore, James R. 2005. "Revolution of the Space Invaders: Darwin and Wallace on the Geography of Life." In Geography and Revolution, edited by David N. Livingstone and Charles W. J. Withers, pp. 106-132. Chicago: University of Chicago Press.

- 2007. "R. A. Fisher: A Faith Fit for Eugenics." Stud. Hist. and Phil. Biol. and Biomed. Sci. 38: 110-135.

Morrell, Jack. 2005. John Phillips and the Business of Victorian Science. Aldershot: Ashgate.

Numbers, Ronald L. 2006. The Creationists. New ed. Cambridge, Mass.: Harvard University Press.

O'Connor, Ralph. 2007. The Earth on Show: Fossils and the Poetics of Popular Science, 1802-1856. Chicago: University of Chicago Press.

Owen, Richard. 2007. On the Nature of Limbs. Ed. Ron Amundson. Chicago: University of Chicago Press.

Radick,. Gregory. 2007. The Simian Tongue: The Long Debate about Animal Language. Chicago: University of Chicago Press.

Regal, Brian. 2002. Henry Fairfield Osborn: Race and the Search for the Origins of Man. Aldershot: Ashgate.

Richards, Robert J. 2004. "Michael Ruse's Design for Living." J. Hist. Biol. 37: 25-38.

. 2008. The Tragic Sense of Life: Ernst Haeckel and the Struggle over Evolutionary Thought. Chicago: University of Chicago Press.

Rudwick, M.J.S. 2005. Bursting the Limits of Time: The Reconstruction of Geohistory in the Age of Revolution. Chicago: University of Chicago Press. - 2008. Worlds before Adam: The Reconstruction of Geohistory in the Age of Reform. Chicago: University of Chicago Press. 
Rupke, Nicolaas A. 2008. Alexander von Humboldt: A Metabiography. Chicago: University of Chicago Press.

Ruse, Michael. 2004. "The Romantic Conception of Robert J. Richards." J. Hist. Biol. 37: 3-37.

- 2005. The Evolution-Creation Struggle. Cambridge, Mass.: Harvard University Press.

Ruse, Michael, ed. 2005. "The 'Darwinian Revolution': Whether, What and Whose?" J. Hist. Biol. special issue, 38 , no.1.

Ruse, Michael, and Robert J. Richards, eds. 2009. The Cambridge Companion to the Origin of Species. Cambridge: Cambridge University Press.

Shapiro, Adam R. 2008. "Civic Biology and the Origin of the Anti-Evolution Movement." J. Hist. Biol. 41: 409-433.

Sloan, Phillip R. 2001. "The Sense of Sublimity': Darwin on Nature and Divinity." Osiris 16: 251-269.

Snyder, Laura J. 2006. Reforming Philosophy: A Victorian Debate on Science and Society. Chicago: University of Chicago Press.

Sommer, Marianne. 2007. Bones and Ochre: The Curious Afterlife of the Red Lady of Paviland. Cambridge, Mass.: Harvard University Press.

Tabery, James G. 2004. "The 'Evolutionary Synthesis' of George Udny Yule." J. Hist. Biol. 37: 73-101.

Van Wyhe, John, 2004. Phrenology and the Origins of Victorian Scientific Naturalism. Aldershot: Ashgate.

- 2007. "Mind the Gap: Did Darwin Avoid Publishing His Theory?" Notes and Records Roy. Soc. Lond. 60: 177-205.

Weikart, Richard. 2004. From Darwin to Hitler: Evolutionary Ethics, Eugenics and Racism in Germany. New York: Palgrave Macmillan.

White, Paul. 2003. Thomas Huxley: Making the "Man of Science." Cambridge: Cambridge University Press. 
